\title{
Newly established cell lines from mouse oral epithelium regenerate teeth when combined with dental mesenchyme
}

\author{
Chiho Takahashi • Hiroyuki Yoshida • \\ Akihiko Komine • Kazuhisa Nakao • Takashi Tsuji • \\ Yasuhiro Tomooka
}

Received: 9 June 2009 / Accepted: 10 November 2009 / Published online: 24 December 2009 / Editor: J. Denry Sato

(C) The Author(s) 2009. This article is published with open access at Springerlink.com

\begin{abstract}
The present study attempted to examine whether clonal cell lines of the oral epithelium can differentiate into ameloblasts and regenerate tooth when combined with dental germ mesenchyme. Clonal cell lines with a distinct morphology were established from the oral epithelium of p53-deficient fetal mice at embryonic day 18 (E18). The strain of mouse is shown to be a useful source for establishing clonal and immortalized cell lines from various tissues and at various stages of development. Tooth morphogenesis is almost completed and the oral epithelium is segregated from the dental epithelium at E18. In RT-PCR analysis of cell lines, mucosal epithelial markers (cytokeratin 14) were detected, but ameloblast markers such as amelogenin and ameloblastin were not detected when cells were cultured on plastic dish. They formed stratified epithelia and expressed a specific differentiation marker (CK13) in the upper layer when cultured on feeder layer or on collagen gel for 1-3 wk, demonstrating that they are of oral mucosa origin. Next, bioengineered tooth germs were prepared with cell lines and fetal molar mesenchymal tissues and implanted under kidney capsule for 2-3 wk. Five among six cell lines regenerated calcified structures as seen in natural tooth. Our results indicate that some oral epithelial cells at E18 possess the capability to differentiate into ameloblasts. Furthermore, cell lines established in the present study are useful models to study processes in tooth organogenesis and tooth regeneration.
\end{abstract}

C. Takahashi $\cdot$ H. Yoshida $\cdot$ A. Komine $\cdot$ K. Nakao $\cdot$ T. Tsuji $\cdot$

Y. Tomooka $(\square)$

Department of Biological Science and Technology and Tissue

Engineering Research Center, Tokyo University of Science,

Yamazaki 2641,

Noda, Chiba 278-8510, Japan

e-mail: tomoylab@rs.noda.tus.ac.jp
Keywords Oral epithelium · Immortalized cell lines · Tooth regeneration $\cdot p 53$-deficient mouse

\section{Introduction}

At the first stage of tooth development, odontogenic potential first appears in the presumptive dental epithelium which elicits the formation of a dental papilla in ectomesenchymal cells (reviewed by Mina and Kollar 1987; Lumsden 1988). The epithelial instructive information elicits odontogenic response from aggregates of nondental stem cells (Ohazama et al. 2004). Once the determination occurs, the mesenchyme acts instructively to induce enamel organ formation on the epithelium, and the inductive activity is effective even on epithelia with non-oral sources (Kollar and Baird 1970a, b; Hu et al. 2006). These previous studies clearly demonstrated a series of reciprocal and sequential epithelial-mesenchymal interactions. The molecular mechanisms of the interactions have been extensively studied, and possible genes or factors are implied as candidates of signaling or acting (reviewed by Mass and Bei 1997; Miletich and Sharpe 2003; Thesleff 2003).

The dental epithelium is derived from the oral epithelium and differentiates into four cell types: (1) inner enamel epithelium (differentiate into ameloblasts), (2) stratum intermedium, (3) stellate reticulum, and (4) outer enamel epithelium (Kawano et al. 2002). Primary culture of dental epithelial cells has provided useful information, although it has inevitable heterogeneity and limited proliferation activity (Kukita et al. 1992; DenBesten et al. 1998; Matsumura et al. 1998). Immortalized cell lines of the dental epithelium were established spontaneously or with retrovirus transfection (Chen et al. 1992; DenBesten et al. 
1999; Kawano et al. 2002; Nakata et al. 2003). They are useful tools to investigate the mechanisms regulating the expression of specific genes such as amelogenin and ameloblastin. However, none of them were examined whether they were able to regenerate teeth.

We have reported the establishment of clonal cell lines from various tissues of $p 53$-deficient mice (Hanazono et al. 1997, 1998; Minakawa et al. 1998; Tomooka and Aizawa 1998; Hanazono et al. 2001; Tanahashi et al. 2002; Umezu et al. 2003). Recently, we have established a method to prepare bioengineered tooth germ (Nakao et al. 2007). Then, we have established clonal dental epithelial cell lines and demonstrated that they are able to regenerate teeth when incorporated into the bioengineered tooth germs prepared with dental mesenchymal tissues (Komine et al. 2007).

In the present study, clonal cell lines were newly established from oral epithelium of $p 53$-deficient fetuses at embryonic day 18. They were characterized and examined whether they are able to differentiate into ameloblasts and regenerate tooth structures when incorporated into the bioengineered tooth germs prepared with dental mesenchymal tissues

\section{Materials and Methods}

Animals. p53 mice (hybrid between C57BL/6 and CBA; Tsukada et al. 1993), CD-1 mice (Charles River Japan, Yokohama, Japan), and C57BL/6 mice (CLEA Japan Inc., Tokyo, Japan) were maintained in the experimental animal facility of Tokyo University of Science. They were kept under a 12:12-h light-dark cycle at $22-24^{\circ} \mathrm{C}$. Standard laboratory feed (MR standard, Nousan LTD, Yokohama, Japan) and tap water were given ad libitum. Mice care and handling conformed to the guidelines for animal research of the National Institutes of Health. The institutional Animal Care and Use Committee approved the experimental protocols.

Cloning and cell culture. Buccal mucosas between the upper and lower maxillae (not containing diastema) were dissected from $p 53$-deficient mice on embryonic day 18 (E18). Tissues were washed several times with phosphatebuffered saline (PBS). The tissues were cut into small pieces with razor blades and treated with $1.2 \mathrm{U} / \mathrm{ml}$ dispase (Roche, Mannheim, Germany) at room temperature for $15 \mathrm{~min}$. Epithelial fragments were separated from the lamina propria with forceps. After gentle trituration with a micropipette, epithelial cells were cultured on 100-mm tissue culture dishes (FALCON; Becton Dickinson Labware, Franklin Lakes, NJ). Cells were maintained at $37^{\circ} \mathrm{C}$ in a humidified incubator $\left(95 \%\right.$ air and $\left.5 \% \mathrm{CO}_{2}\right)$. Culture medium was a 1:1 mixture of Dulbecco's modified Eagle's medium and Ham's nutrient F-12 (DMEM/F12; Sigma, Chemical Company, St. Louis, MO) containing heatinactivated fetal calf serum at $10 \%(10 \% \mathrm{FCS}, v / v$; HyClone, Logan, UT), supplemented with penicillin (31 $\mu \mathrm{g} / \mathrm{ml}$, Sigma), streptomycin $(50 \mu \mathrm{g} / \mathrm{ml}$, Sigma), transferrin (T; $10 \mu \mathrm{g} / \mathrm{ml}$, Sigma), insulin (I; $10 \mu \mathrm{g} / \mathrm{ml}$, Sigma), and cholera toxin (C; $10 \mathrm{ng} / \mathrm{ml}$, Sigma). Cloning was done by limited dilution as described previously (Umezu et al. 2003). Many clonal cell lines were established, and eight lines with a distinct morphology were analyzed in detail in the present study. They were named foec (fetal oral epithelial cell) -1 to -8 . They were passaged at $1 / 20$ in $60-\mathrm{mm}$ dishes.

Immunocytochemistry. Immunocytochemistry was done as described previously (Komine et al. 2007). In brief, cells were fixed in $95 \%$ ethanol containing $1 \%$ acetic acid or $4 \%$ formaldehyde and washed with PBS containing $0.05 \%$ Tween 20 (Sigma; PBS-T). They were incubated with primary antibodies overnight at $4^{\circ} \mathrm{C}$. The primary antibodies used were anti-cytokeratin 18 (CK18; Progen Biotechnik GmbH, Heidelberg, Germany), anti-vimentin (Progen), anti-cytokeratin 10 (CK10) (1/10; Progen), anticytokeratin 13 (CK13; 1/10; Progen), anti-cytokeratin 14 (CK14) (1/100; Serotec, Oxford, UK), and anti-p63 (AB-1, 1/100; Calbiochem, Damstadt, Germany) antibodies. After several washes with PBS-T, cells were incubated with fluorescein isothiocyanate (FITC)-conjugated anti-mouse IgG serum (MP Biomedicals, Cleveland, $\mathrm{OH}$ ) for $1.5 \mathrm{~h}$ at room temperature (RT). Negative controls were incubated without primary antibodies.

Immunoblot analysis. When cells became confluent in 100-mm dishes, medium was removed and cells were washed several times with PBS. Then, $120 \mu \mathrm{l}$ of sample buffer $(62.5 \mathrm{mM}$ Tris- $\mathrm{HCl}, \mathrm{pH}$ 6.8) containing $10 \%$ glycerol (Wako Pure Chemical Industries, Ltd., Osaka, Japan) 2\% sodium dodecyl sulfate (SDS; Wako) $5 \%$ 2-mercaptoethanol (Wako), and $0.5 \mathrm{mM}$ phenylmethane sulfonyl fluoride (Sigma) was added to the dishes. Cells were collected with a cell lifter at $4^{\circ} \mathrm{C}$. After sonication and centrifugation, the supernatant was boiled for $10 \mathrm{~min}$ at $95^{\circ} \mathrm{C}$ and stored at $-80^{\circ} \mathrm{C}$ until analysis. Protein concentrations of these samples were determined with Micro BCA Protein Assay Reagent Kit (Pierce Chemical Co. Rockford, IL) according to the manufacturer's instruction. Samples containing $50 \mu \mathrm{g}$ protein were electrophoresed on 10\% SDS-polyacrylamide gels and transferred to polyvinylidine difluoride membranes (Immobilon-P; Millipore, Bedford, MA) for $90 \mathrm{~min}$ at RT using a transblot semidry transfer cell. Nonspecific binding was blocked by incubation with $20 \mathrm{mM}$ Tris- 
buffered saline ( $\mathrm{pH} 7.6$ ) containing $0.05 \%$ Tween 20 (TBS-T) in $10 \%$ skimmed milk overnight at $4{ }^{\circ} \mathrm{C}$. Membranes were incubated with primary antibodies for $1-2 \mathrm{~h}$ at RT. The primary antibodies used were anti-CK18, anti-CK14 (1/10), and anti-vimentin mouse monoclonal antibodies diluted with TBS-T containing 5\% skimmed milk (TBS-T-SM). After several washes with TBS-T-SM, the membranes were incubated with horseradish peroxidase-conjugated antibodies (1/5000; MP Biomedicals) for $1 \mathrm{~h}$ at RT. They were washed with TBS-T-SM twice for $10 \mathrm{~min}$ and rinsed with TBS-T once. Membrane-bound antibodies were detected by chemiluminescence with ECL Western Blotting Detection Reagents (Amersham Biosciences, Buckinghamshre, UK) according to the manufacture's instruction and exposed to X-ray film (Amersham Biosciences).

RT-PCR. Total RNA was extracted using SV Total RNA Isolation System (Promega, Madison, WI) from epithelial cell lines, adult and fetal brains (CD-1 mouse), incisor epithelia (C57BL/6 mouse) and a dental epithelial cell line emtg-3 (Komine et al. 2007). About 5 or $1 \mu \mathrm{g}$ of total RNA was used for the generation of first-strand cDNA using First-Strand cDNA Synthesis Kit (Amersham Biosciences) according to manufacturer's instructions. cDNA was used as template for PCR for each gene; CD71, $\beta 1$-integrin, $\beta 4$ integrin, $\alpha 6$-integrin, amelogenin, ameloblastin, Msx2, p75NGFR, mBD1, PlexinA1-4, and GAPDH (Table 1). PCR conditions were 35 cycles of $94^{\circ} \mathrm{C}$ for $1 \mathrm{~min}, 56^{\circ} \mathrm{C}$ for $1 \mathrm{~min}, 72^{\circ} \mathrm{C}$ for $1 \mathrm{~min}(\mathrm{CD} 71, \beta 1$-integrin, $\beta$ 4-integrin, $\alpha 6$-integrin, p75NGFR, GAPDH; Table 1), 30 cycles of $94^{\circ} \mathrm{C}$ for $1 \mathrm{~min}, 56^{\circ} \mathrm{C}$ for $1 \mathrm{~min}, 72^{\circ} \mathrm{C}$ for $1 \mathrm{~min}(\mathrm{mBD} 1$, amelogenin, p75NGFR), 30 cycles of $94^{\circ} \mathrm{C}$ for $30 \mathrm{~s}, 56^{\circ} \mathrm{C}$ for $30 \mathrm{~s}, 72^{\circ} \mathrm{C}$ for $1 \mathrm{~min}$ (ameloblastin), 35 cycles of $94^{\circ} \mathrm{C}$ for $1 \mathrm{~min}, 60^{\circ} \mathrm{C}$ for $1 \mathrm{~min}, 72^{\circ} \mathrm{C}$ for $1 \mathrm{~min}$ (ameloblastin), and 30 cycles of $94^{\circ} \mathrm{C}$ for $30 \mathrm{~s}, 57^{\circ} \mathrm{C}$ for $30 \mathrm{~s}, 72^{\circ} \mathrm{C}$ for 1 min (PlexinA1-4). The amplified products were analyzed by electrophoresis in $2.0 \%$ (amelogenin), $1.5 \%$ (CD71, $\beta 1$ integrin, $\beta 4$-integrin, $\alpha 6$-integrin, PlexinA1-4), or $1.0 \%$ (mBD1, ameloblastin, Msx2, p75NGFR, GAPDH) agarose gel containing ethidium bromide.

Culture on feeder layer. Balb/c 3T3 cells were maintained in $10 \% \mathrm{FCS}$. After treatment with mytomycin C (Sigma) at $4 \mu \mathrm{g} / \mathrm{ml}$ for $2 \mathrm{~h}$ in DMEM without FCS, they were cultured $10 \% \mathrm{FCS}$ for $24 \mathrm{~h}$. Then, they were collected after trypsinEDTA treatment and seeded on six-multiwell plates (FALCON) at a density of $2 \times 10^{4}$ cells/well. Epithelial cells were seeded on the feeder layer at a density of $1 \times$ $10^{5}$ cells/well and cultured in $10 \% \mathrm{FCS}$ supplemented with $\mathrm{I}, \mathrm{T}, \mathrm{C}, 0.5 \mu \mathrm{g} / \mathrm{ml}$ hydrocortisone (Sigma), and $10 \mathrm{ng} / \mathrm{ml}$ EGF (Roche Diagnostics). After 7-14 d in culture, epithelial sheets were harvested and prepared for histology and immunohistochemistry.
Three-dimensional co-culture with collagen gel. Threedimensional co-culture was prepared as described previously (Schoop et al. 1999) with a slight modification. Eight volumes of ice-cold acidic collagen solution was mixed with one volume $10 \times$ Waymouth's medium and neutralized with $1 \mathrm{~N} \mathrm{NaOH}$ at $4^{\circ} \mathrm{C}$. Collagen was extracted from mouse tail tendons by a modified method (Tomooka et al. 1993). One volume of 3D medium (see below) containing Balb/c 3 T3 cells $\left(5 \times 10^{6}\right.$ cells $\left./ \mathrm{ml}\right)$ was added. The final solution $(2.5 \mathrm{ml})$ was plated into cell culture inserts (polyethylene terephthalate, $3.0-\mu \mathrm{m}$ pore size, FALCON) in 6-multiwell plates (FALCON). For polymerization, the mixture was incubated at $37^{\circ} \mathrm{C}$ for at least $30 \mathrm{~min}$. Collagen lattices were cultured in 3D medium: DMEM/F12 containing 10\%FCS supplemented with I, T, C, hydrocortisone, EGF, and $50 \mu \mathrm{g} / \mathrm{ml}$ ascorbic acid (Wako). On the following day, epithelial cells $\left(1 \times 10^{6}\right.$ cells/well $)$ were plated on the lattices and cultured in submerged state. Epithelial cells were precultured in Defined Keratinocyte-SFM (Invitrogen Corp. Carlsbad, CA) for at least $1 \mathrm{wk}$. After another day, the inserts were raised to air-liquid interface. Threedimensional medium was replaced every d. After 1$3 \mathrm{wk}$, the inserts were harvested and prepared for histology and immunohistochemistry.

Histology and immunohistochemistry. For histology, samples were fixed in $95 \%$ ethanol containing $1 \%$ acetic acid (CK13, CK14) or $4 \%$ formaldehyde (p63 $\alpha, \beta 1$-integrin) at $4{ }^{\circ} \mathrm{C}$ overnight and dehydrated and decalcified with $4.5 \%$ EDTA (pH 7.4) overnight at $4{ }^{\circ} \mathrm{C}$. They were embedded in paraffin and cut into $8-\mu \mathrm{m}$ sections, or embedded in OCT compound (Sakura Finetek, Torrance, CA), and cut into $10-\mu \mathrm{m}$ transversal frozen sections. Sections were stained with hematoxylin and eosin. Sections for immunohistochemistry were incubated with primary antibodies: p63 (H-129, 1/100; Santa Cruz Biotechnik, Heidelberg, Germany), anti- CK13 (1/20; American Research Products, Palos Verdes, CA), CK14 $(1 / 100 ;$ Serotec), and $\beta 1$-integrin $(1 / 20$, BD PharMingen, San Jose, CA) antibodies. After several washes with PBS-T, sections were incubated with FITC-conjugated anti-mouse IgG serum (1/200; MP Biomedicals), Cy3-conjugated antirabbit IgG serum (1/200; Jackson ImmunoResearch, West Grove, PA), or Cy3-conjugateed anti-rat IgG serum (1/200; Jackson ImmunoResearch) for $1.5 \mathrm{~h}$ at RT. Nuclei were stained with DAPI. In immunohistochemistry for CK13 and CK14, sections were digested for $1 \mathrm{~min}$ in $0.2 \times$ Trypsin EDTA (Sigma) and boiled for $10 \mathrm{~min}$ in $10 \mathrm{mmol} / \mathrm{l}$ citric acid, $\mathrm{pH} 6.0$, in a microwave oven. Sections were processed for primary antibodies.

Reconstruction of bioengineered tooth germs. The procedure of tooth germ reconstruction was recently established 
Table 1. Sequences of primers for RT-PCR

\begin{tabular}{lllc}
\hline Genes & Forward primer & Reverse primer & Product size (bp) \\
\hline CD71 & atcaagccagatcagcattc & agcctcacgaggagtgtatg & 472 \\
$\beta$ 1-integrin & tggcaacaatgaagctatcg & tgtgacctcagctgacaagg & 504 \\
$\beta 4$-integrin & acctggtgacctgtgagatg & ctaggagaggaggcaaggag & 501 \\
$\alpha 6$-integrin & gctatgatgtggcagtggtg & ggcggaggtcaattctgtta & 504 \\
amelogenin & gaagccctggttatatcaacttaagc & gctgccttatcatgctctggta & 75 \\
ameloblastin & ttgcaggaaggagagctgat & cagtggagagccttctggac & 444 \\
Msx2 & gcgcaagttccgccagaaacagta & gtgagaggaaagggggcatttgga & 549 \\
p7.5NGFR & cagtggagagtgctgcaaag & ggaggacacgagtcctgagc & 295 \\
mBD1 & tgttggcattctcacaagtc & accgtgttctctgttccatt & 451 \\
PlexinA1 & tctggaggtacctggattgg & agggtccggtagtagagga & 531 \\
PlexinA2 & ccaagtcccaccagcactat & acaggtgagggtggttgtgt & 464 \\
PlexinA3 & tgtcagtgctgaaaggatcg & cattgatgatgctccaggtg & 446 \\
PlexinA4 & tggcattccagtcttcacag & cacaggacaggcatgaattg & 737 \\
GAPDH & accacagtccatgccatcac & tccaccaccctgttgctgta & 452 \\
\hline
\end{tabular}

by us (Nakao et al. 2007). In brief, tooth germs were dissected from lower molars of CD-1 mouse embryos at E16.5 and incubated in PBS containing 1.2 U/ml dispase II (Roche) for $15 \mathrm{~min}$ at RT. Epithelial and mesenchymal fractions were separated with a fine needle. The mesenchymal fraction was divided into a first molar and a second molar with fine needles under a stereoscopic microscope. The first molar mesenchyme tissues were used for combination with oral epithelial cell lines or tooth epithelial cells. Epithelial fractions were treated with $100 \mathrm{U} / \mathrm{ml}$ collagenase type I (Worthington Biochemical Co. Lakewood, NJ) for $20 \mathrm{~min}$ at $37^{\circ} \mathrm{C}$. After several washings with PBS, they were treated with $0.5 \times$ Trypsin-EDTA (Sigma) for $5 \mathrm{~min}$ at $37^{\circ} \mathrm{C}$ and dispersed. The tooth epithelial cells were centrifuged to make pellets. Cells of oral epithelial cell lines were detached from culture dishes with trypsinEDTA and were centrifuged to make pellets. A part of the pellet containing approximately $1 \times 10^{5}$ tooth epithelial cells (as positive control) or oral cell lines was put on a mesenchymal tissue in $30 \mu \mathrm{l}$ Cell matrix type I-A (Nitta Gelatin Inc., Osaka, Japan) and incubated in a humidified atmosphere of $95 \%$ air and $5 \% \mathrm{CO}_{2}$ at $37^{\circ} \mathrm{C}$. On the following day, the collagen gel containing tissues was implanted under kidney capsule of CD-1 adult mice. Two cell lines (foec-2 and foec-5) were labeled with enhanced green fluorescent protein by transfection using Lipofec$\operatorname{tin}^{\mathrm{TM}}$ reagent (Invitrogen Corp). They were also used for germ reconstruction. Kidneys were harvested and prepared for histology and immunohistochemistry as described below. Germs prepared with only epithelial cells gave rise to a remnant mass of cells (data not shown).

Kidneys were fixed in $4 \%$ formaldehyde at $4{ }^{\circ} \mathrm{C}$ and decalcified with Morse's solution and dehydrated with graded alcohol. They were embedded in paraffin and cut into 8 - $\mu \mathrm{m}$ sections. Kidneys with germs reconstructed with epithelial cells labeled with green fluorescent protein (GFP) were decalcified with $10 \%$ EDTA ( $\mathrm{pH} 7.4$ ) overnight at $4^{\circ} \mathrm{C}$. Then, they were embedded in OCT compound and cut into $12-\mu \mathrm{m}$ frozen sections. Sections were stained with hematoxylin and eosin or incubated with anti-amelogenin polyclonal antibody (1/200; Hokudo, Hokkaido, Japan) overnight at $4{ }^{\circ} \mathrm{C}$ and with FITC-conjugated anti-rabbit IgG serum (1/200; CHEMICON International, Temecula, CA). Nuclei were stained with DAPI.

\section{Results}

Morphology of clonal cell lines. Eight clonal lines with a distinct morphology were characterized in the present study. At low density, foec- 1 , foec- 2 , and foec- 4 cells were round in shape. foec- 3 , foec- 5 , foec- 7 , and foec- 8 cells had elongated shape, and foec- 6 cells had small processes. At high density, intercellular boundary became unclear in foec-1, foec-4, and foec-6 cells (Fig. 1).

Marker expression in cell lines. Marker expression was analyzed in all cell lines with immunocytochemistry and Western blotting. The results are shown in Fig. 2 and summarized in Table 2. All cell lines were immunoreactive for an epithelial cell marker CK14, but not for a fibroblast marker vimentin (Fig. 2B). CK13, a differentiation marker of non-keratinized epithelia, was undetected ( 3 in Fig. 2A). CK18, a marker of simple epithelia, was immunocytochemically undetected ( 5 in Fig. $2 A$ ) or weakly detected in some cells of foec-7 and -8 lines (data not shown). In Western blotting, CK18 was weakly detected in only foec-7 line (Fig. 2B). CK10 was not detectable in any of cell lines ( 2 in Fig. $2 A$ ). p63 protein was detected in all cell lines ( 6 in 

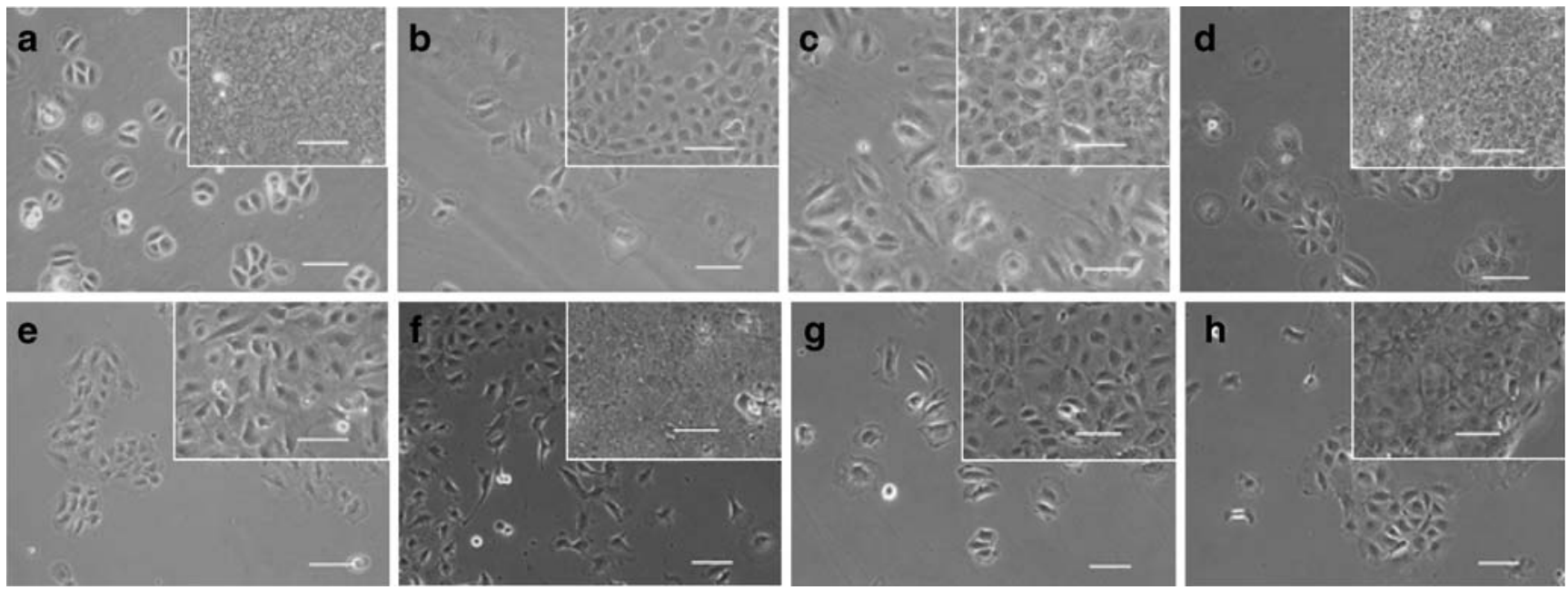

Figure 1. Morphology of clonal cell lines. foec-1 cells $(a)$, foec-2 cells $(b)$, foec- 3 cells $(c)$, foec- 4 cells $(d)$, foec-5 cells $(e)$, foec-6 cells $(f)$, foec-7 cells $(g)$, and foec- 8 cells $(h)$. They had a distinct

Fig. 2A). Some cells of foec- 7 and -8 lines were negative for $\mathrm{p} 63$ (data not shown).

RT-PCR analysis was performed on six cell lines (foec-2, $3,5,6,7$, and 8) to investigate gene expression of various epithelial markers (Fig. 3). There were no differences in the expression pattern of undifferentiated epithelial markers (CD71, $\beta 1$-integrin, $\beta 4$-integrin, $\alpha 6$-integrin) among cell lines (Fig. 3A). RT-PCR analysis was also conducted on the six cell lines on genes specifically expressed in oral or dental epithelium (Fig. $3 B$ ). $m B D 1$ specifically expressed in

morphology when cultured on plastic dish in $10 \% \mathrm{FCS}$ supplemented with transferrin, insulin, and cholera toxin. Inserts were at high density. Bar, $50 \mu \mathrm{m}$.

the mucosal epithelium was detected in oral epithelial cell lines except for foec-5 line. Amelogenin and ameloblastin, ameloblast-specific marker genes, were undetected in any of cell lines. Msx 2 was detected in ameloblasts prepared from incisors and some of oral epithelial cell lines. $p 75 N G F R$ was detected in all cell lines.

RT-PCR analysis was conducted on the six cell lines on plexin expression (Fig. 3C). Different patterns of plexin expression are reported between tooth germ and oral epithelium at embryonic stage (Perälä et al. 2005). Plxnal

Figure 2. Immunochemical analyses of foec lines. Immunocytochemistry of epithelial and mesenchymal marker proteins in foec-2 line $(A)$. Vimentin (1), CK10 (2), CK13 (3), and CK18 (5) were not detected. CK14 (4) and p63 (6) were detected. Nuclei were stained with DAPI in (6). Bar, $100 \mu \mathrm{m}$. Western blotting $(B)$ detected CK14 in all lines. CK18 was weakly detected only in foec-7 line. Vimentin was not detected in any lines. Tongue was used as control.
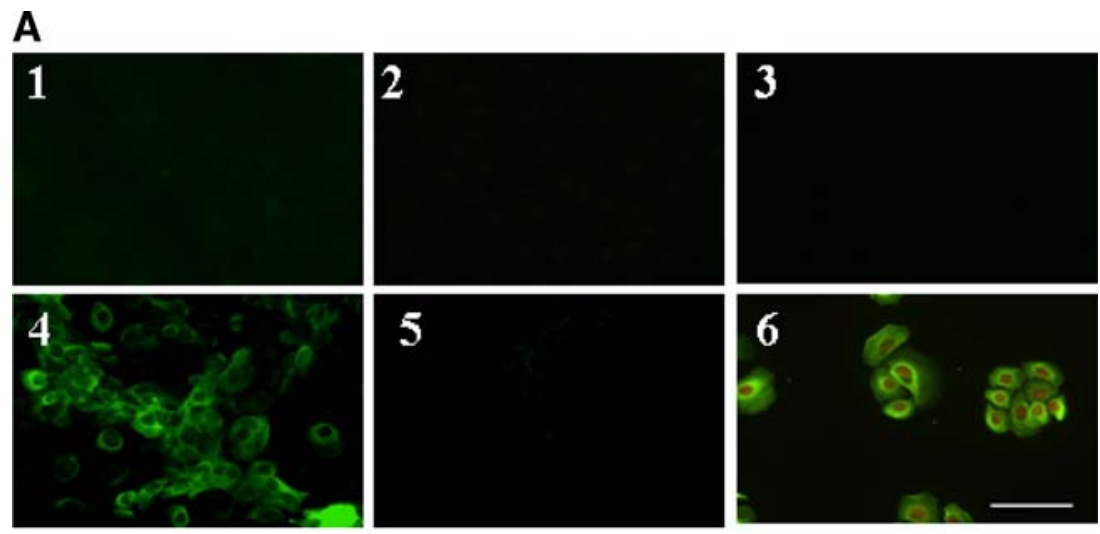

B

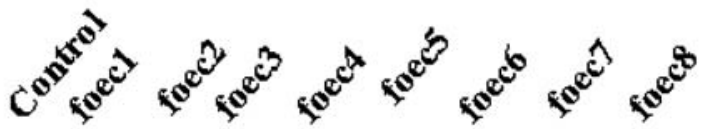

CK14

CK18

Vimentin

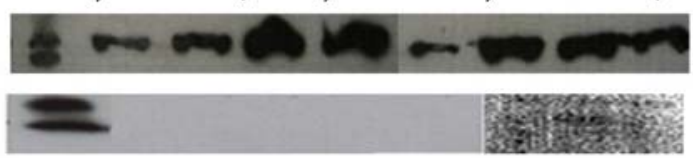


Table 2. Summary of immunocytochemistry and Western blotting of marker expression

\begin{tabular}{|c|c|c|c|c|c|c|c|c|c|}
\hline \multicolumn{7}{|c|}{ Immunocytochemistry } & \multicolumn{3}{|c|}{ Western blotting } \\
\hline Cell line & $\mathrm{V}$ & CK10 & CK13 & CK14 & CK18 & p63 & $\mathrm{V}$ & CK14 & CK18 \\
\hline foec-1 & - & - & - & + & - & + & - & + & - \\
\hline foec-2 & - & - & - & + & - & + & - & + & - \\
\hline foec- 3 & - & - & - & + & - & + & - & + & - \\
\hline foec-4 & - & - & - & + & - & + & - & + & - \\
\hline foec-5 & - & - & - & + & - & + & - & + & - \\
\hline foec- 6 & - & - & - & + & - & + & - & + & - \\
\hline foec-7 & - & - & - & + & $+/-$ & $+/-$ & - & + & + \\
\hline foec- 8 & - & - & - & + & $+/-$ & $+/-$ & - & + & - \\
\hline
\end{tabular}

was detected in all oral cell lines and a dental epithelial cell line emtg-3. Plxna2 and plxna3 were detected in all oral epithelial cell lines, but not in emtg-3. Plxna4 was undetected in any cell lines examined. Control was prepared from adult brains (Plxna1, 2, and 4) and fetal brains (Plxna3).

Induction of stratified oral epithelium. Oral mucosa (E18.5) are stratified and express CK14 at the basal layer and CK13 at the superficial layer. p63 is strongly expressed at the basal cells on the $\beta 1$-integrin positive basement membrane (Fig. 4). The question was addressed whether the six cell lines are able to differentiate into stratified oral epithelium. Stratified epithelia with two to three cell layers were formed when foec-5 cells were cultured on feeder layer (Fig. 5a). CK13, a differentiation marker, was detected at the surface of the epithelia (Fig. 5b), and CK14 was detected in all cell layers (Fig. 5c). p63 protein, an epithelial stem cell marker, was detected in cuboidal cells at the basal layer (Fig. $5 d$ ). The same results were observed on the other five cell lines (data not shown).

Oral epithelial cells were cultured on collagen gel containing Balb/c $3 \mathrm{~T} 3$ cells (Fig. 6). foec-8 and foec-6 cells formed stratified epithelia (Fig. $6 a, e$ ). Cells were cuboidal at the basal layer, and cell shape became flat at the upper layers toward the surface as seen in the adult oral epithelium. CK13 was detected in superficial layers (Fig. 6b,f). CK14 was detected in all cell layers (Fig. 6c, $g$ ), and $\beta 1$-integrin was detected in basal cells (Fig. $6 d, h$ ). The same results were observed on the other four cell lines (data not shown).

Regeneration of tooth. The question was addressed whether oral epithelial cell lines are able to regenerate tooth. Tooth germs were reconstructed with the six cell lines (foec-2, -3 , $-5,-6,-7$, and -8 lines) and fetal dental mesenchyme. They were implanted under kidney capsule for 2-3 wk. The bioengineered germs developed teeth with calcified struc- tures as seen in natural tooth ( 1 and 2 in Fig. 7). Ameloblasts were polarized and regularly lined up along with calcified enamel (3 in Fig. 7). Amelogenin, an ameloblast-specific protein, was detected in these differentiated ameloblasts and residues of enamel (4 and 5 in Fig. 7). All teeth had molar structure. As summarized in Table 3, successful regeneration of teeth was varied among cell lines $(20-43 \%)$. None of the germs prepared with foec3 cells developed tooth. Such germs developed non-tooth tissues such as keratinized tissues (6 in Fig. 7), osteogenic tissues ( 7 in Fig. 7), and partial odontogenic or unidentified cell aggregations (data not shown).

Germs were prepared with foec-2 and -5 cells labeled with GFP and transplanted under kidney capsule for $2-$ 3 wk. GFP-expressing cells were found around the calcified tissue and differentiated into amelogenin-positive ameloblasts (Fig. 8).

\section{Discussion}

Characters of established cell lines. A number of clonal cell lines were established from various kinds of tissues of p53-deficient mice (Hanazono et al. 1997, 1998; Minakawa et al. 1998; Tomooka and Aizawa 1998; Hanazono et al. 2001; Tanahashi et al. 2002; Umezu et al. 2003; Komine et al. 2007). None of the cell lines had anchorage-independent growth or subcutaneous growth in nude mice, suggesting that they are not tumorigenic.

Epithelial cells are known to express various subtypes of cytokeratin $(\mathrm{CK})$, and the expression pattern is restrictively specific for each epithelium and position in the tissue. CK14 is expressed in stratified squamous epithelia in vivo and is also expressed in epithelial cells in primary culture (Byrne et al. 1994; Koster et al. 2004). All of the established cell lines in the present study expressed CK14, but not CK10 which is expressed in keratinized epithelia (Mackenzie et al. 1991; Gao and Mackenzie 1992). CK13 
Figure 3. RT-PCR analyses of gene expression. Expressions of undifferentiated epithelial marker genes $(A)$ were observed in all lines examined. emtg-3 line is a dental epithelial line. Oral epithelium (E18) was used as control. Expression of tissuespecific epithelial marker genes was examined $(B) . m B D 1$, a mucosal epithelium-specific gene, was detected in foec-2, -3 , $-6,-7$, and -8 lines, but not in foec- 5 and ameloblasts prepared from incisors. Ameloblastspecific genes (amelogenin and ameloblastin) were undetected in any of oral cell lines. Plexin expression was examined $(C)$. Plxnal was detected in all cell lines. Plxna 2 and plxna 3 were undetected in emtg-3. Plxna4 was undetected in any cell lines. Control was prepared from fetal and adult brains.
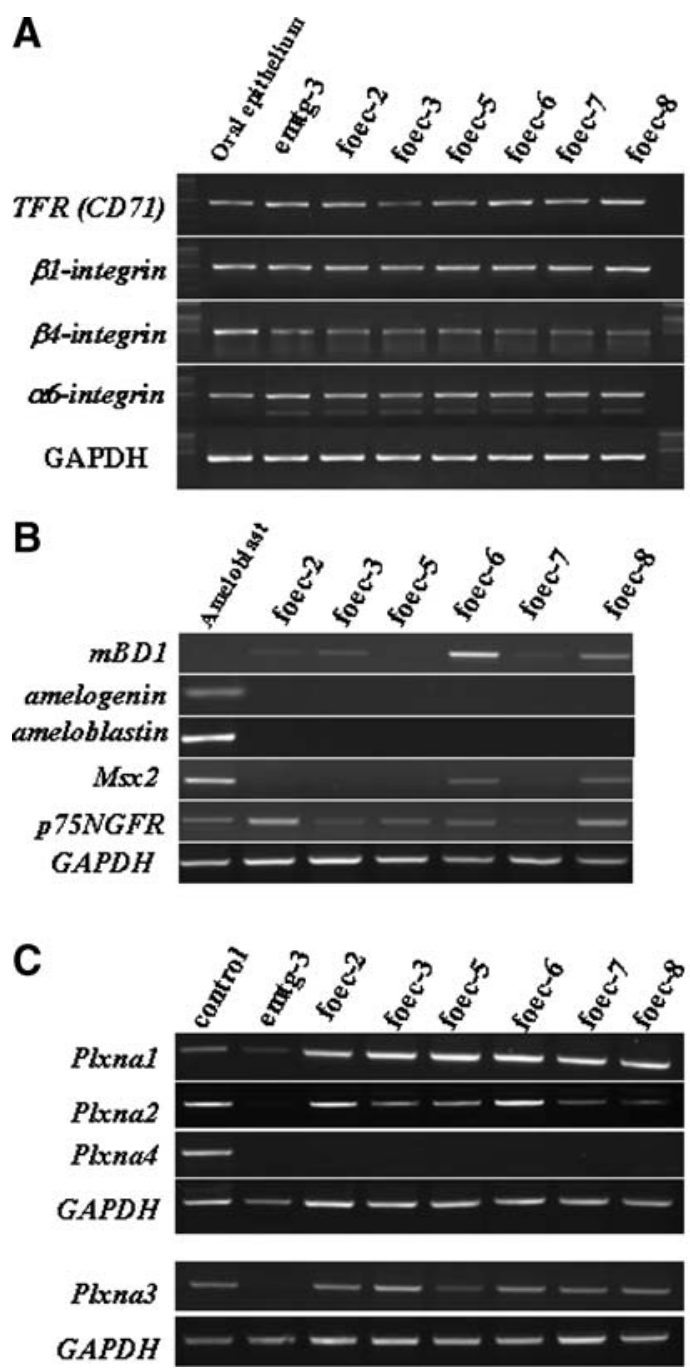

Undifferentiated epithelial marker genes

Tissue specific epithelial marker genes is expressed in differentiated epithelial cells of nonkeratinized epithelia (Gao and Mackenzie 1992; FeghaliAssaly et al. 1994). CK13 expression was undetected when cells were cultured on plastic dish. CK13 became detectable in stratified layers as seen in oral mucosa. CK18 is expressed in the surface ectoderm prior to stratification and in simple epithelia of adult (Jackson et al. 1981; reviewed by Moll et al. 1982). CK18-positive cells were observed sporadically in foec- 7 and -8 cells. The significance and mechanism is not known for the ectopical expression.

p63 is expressed in cells at the basal layer of stratified epithelia (Yang et al. 1998) and considered as an epithelial stem cell marker. The p63 expression is supposed to be a trigger for stratification (Koster et al. 2004). p63 protein was expressed in almost all cells of all cell lines.

In the present study, multiple clonal lines with a distinct morphology were established. Such results were obtained in our previous studies of epithelia of uterus (Hanazono et al. 1997), vagina (Tanahashi et al. 2002), oviduct (Umezu et al. 2003), and tooth germ (Komine et al. 2007). Multiple populations of epithelial cells with a distinct morphology were recognized in primary culture prior to cloning of these epithelia as well as oral epithelium in the present study (data not shown). The buccal region of the oral epithelium is non-keratinized stratified epithelium in which histological heterogeneity is not reported. Stratified epithelia such as epidermis have multiple types of cells at different stages of differentiation: stem cells at the basal layer, transit amplifying cells at the intermediate layer, and differentiated cells at surface layer (Jones et al. 1995; Tani et al. 2000). The transit amplifying cells were thought to be restricted in proliferation, but it was shown that transit amplifying cells are also mitotic as well as stem cells (Li et al. 2004), suggesting the possibility that cell lines could be established from transit amplifying cells in stratified epithelia of p53-deficient mice. Non-stratified epithelia lack such transit amplifying cells, although multiple epithelial cell lines with a distinct morphology were established from uterine and oviduct epithelia (Hanazono et al. 1997; Umezu et al. 

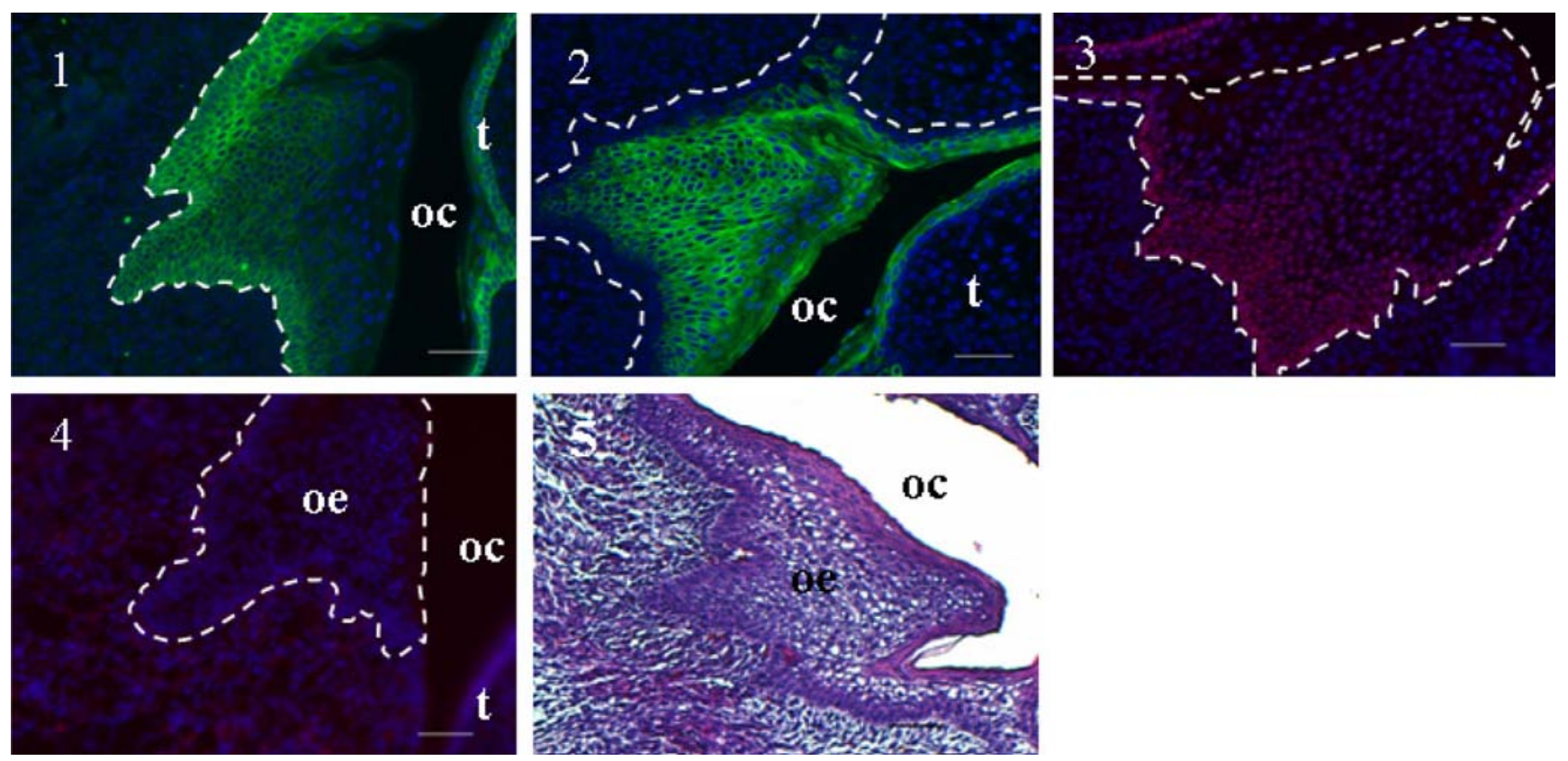

Figure 4. Immunohistochemistry of fetal oral mucosa (E18.5). The basal layer of stratified epithelia was positive for CK14 (1). CK13 was detected in stratified epithelia except the basal layer (2). p63 was strongly detected at the basal layer and immunoreactivity became

2003). Taken together, it is possible that heterogeneity or chimerism is of nature in the oral epithelium and not the results of continuous proliferation in culture or lack of $p 53$.

$\beta$-defensins are cationic antimicrobial peptides and contribute to protect mucosal surface (Miyasaki et al. 1990). Mouse $\beta$-defensin 1 ( $m B D 1)$ was used as a specific marker of oral epithelial cells. $m B D 1$ expression was detected in all epithelial lines except for foec-5 line. Plexins were used as stage-dependent specific markers. Plexins are weaker toward to the surface (3). $\beta 1$-integrin was detected at the basement membrane along the dotted line (4). (5) was H-E staining. $O C$ oral cavity, $O E$ oral epithelium, $t$ tongue. Bar, $50 \mu \mathrm{m}$.

large transmembrane proteins and are receptors for semaphorins. Recently, it is reported that plexins play roles in the morphogenesis of various non-neuronal tissues (Kagoshima et al. 2001; Fujii et al. 2002; Toyofuku et al. 2004). Different expression patterns of plexin are observed in mouse tooth germ and oral epithelium at embryonic stage (Perälä et al. 2005). The present study also confirmed such specific expression of plexin in epithelial cell lines established from the oral epithelium. Taken together, cell
Figure 5. Reconstructed oral epithelia on feeder layer. foec- 5 line formed epithelia with 2-3 cell layers ( $a$, H-E staining). CK13 was detected only in cells at the surface $(b)$. CK14 was detected in all cells $(c)$. p63 protein was detected in cuboidal cells at the basal layer $(d)$.

Nuclei were stained with DAPI. Bar, $20 \mu \mathrm{m}$.
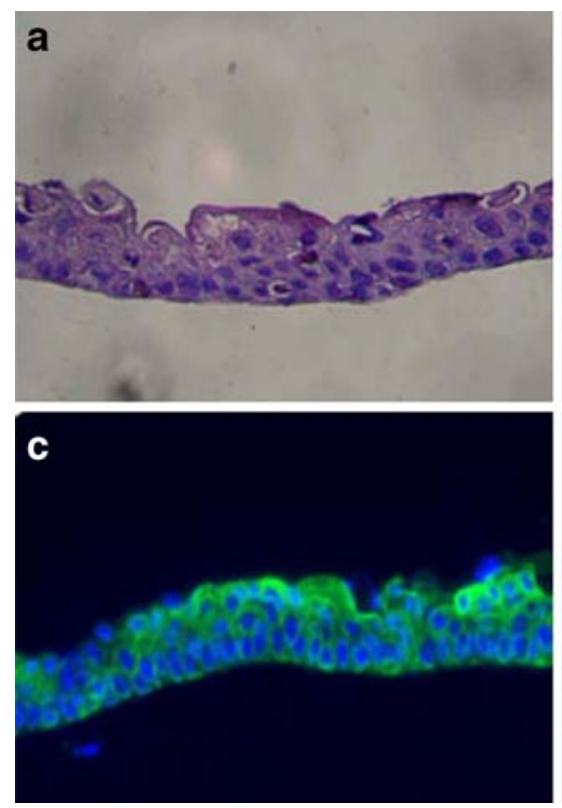
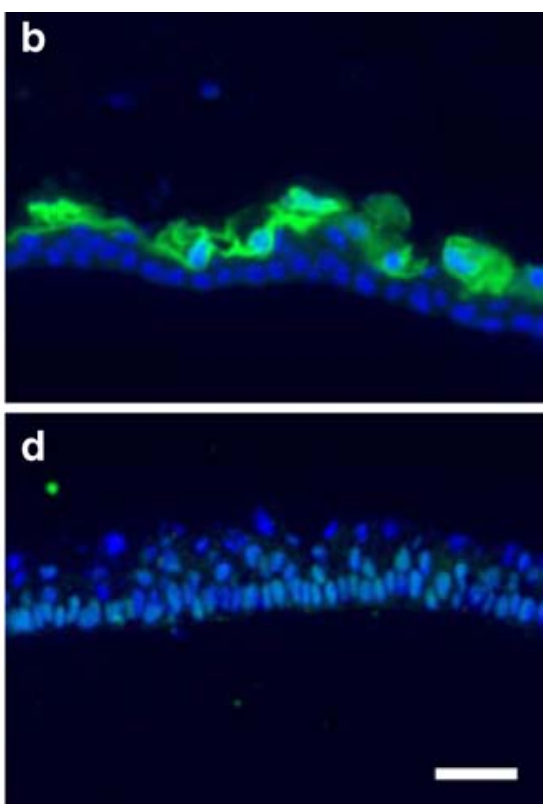

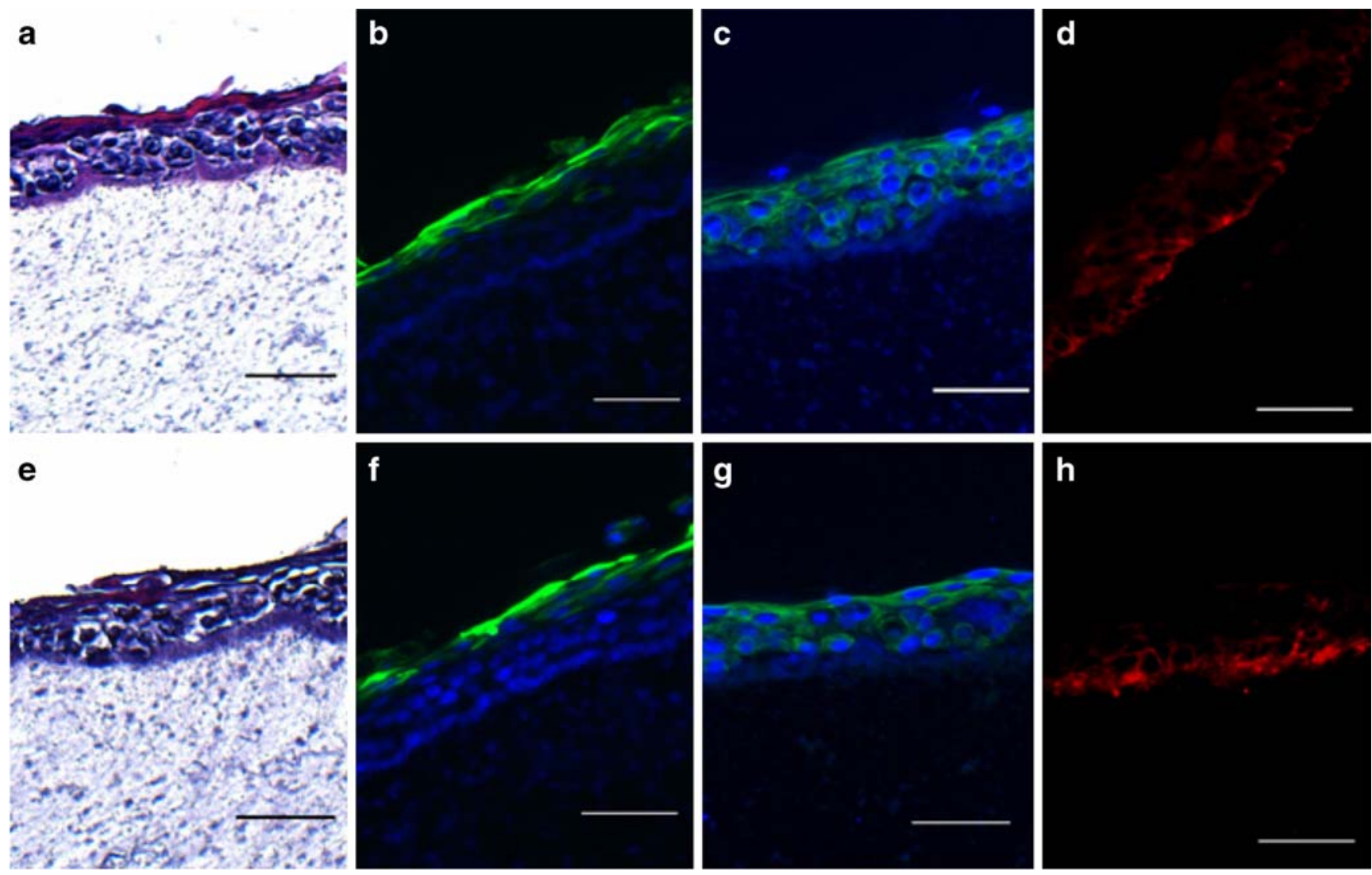

Figure 6. Reconstructed oral epithelia on collagen gel. Top panel is of foec-8 line and bottom panel is of foec- 6 line. Cells were cuboidal at the basal layer, and cell shape became flat toward the surface $(a, e$ $\mathrm{H}-\mathrm{E}$ staining). CK13 was strongly detected in surface layers of foec-

$8(b)$ and foec-6 lines $(f)$. CK14 was detected in all cells in layers of foec-8 $(c)$ and foec- $6(\mathrm{~g})$ lines. $\beta 1$-integrin was strongly expressed in basal cells of foec-8 $(d)$ and foec-6 $(h)$ lines. Nuclei were stained with DAPI. Bar, $50 \mu \mathrm{m}$

Figure 7. Regenerated teeth with oral epithelial cell lines and dental mesenchyme. Calcified teeth were regenerated from germs prepared with dental mesenchyme and foec-7 (1) and foec-5 cells (2). A rectangle in (2) was enlarged in (3). Ameloblasts regularly lined up along with calcified tissue (3). Amelogenin was detected in differentiated ameloblasts and residues of enamel in a section near (1) (4). A rectangle in (4) was enlarged in (5). Keratinized tissues developed from germs prepared with dental mesenchyme and foec- 2 cells ( 6 ). Osteogenic tissues developed from germs prepared with dental mesenchyme and foec- 6 cells (7). $a$ ameloblast, $d$ dentin, $e$ enamel, $k$ kidney, $o$ odontoblast, $p$ dental pulp. Black bar, $200 \mu \mathrm{m}$; white bar, $50 \mu \mathrm{m}$.
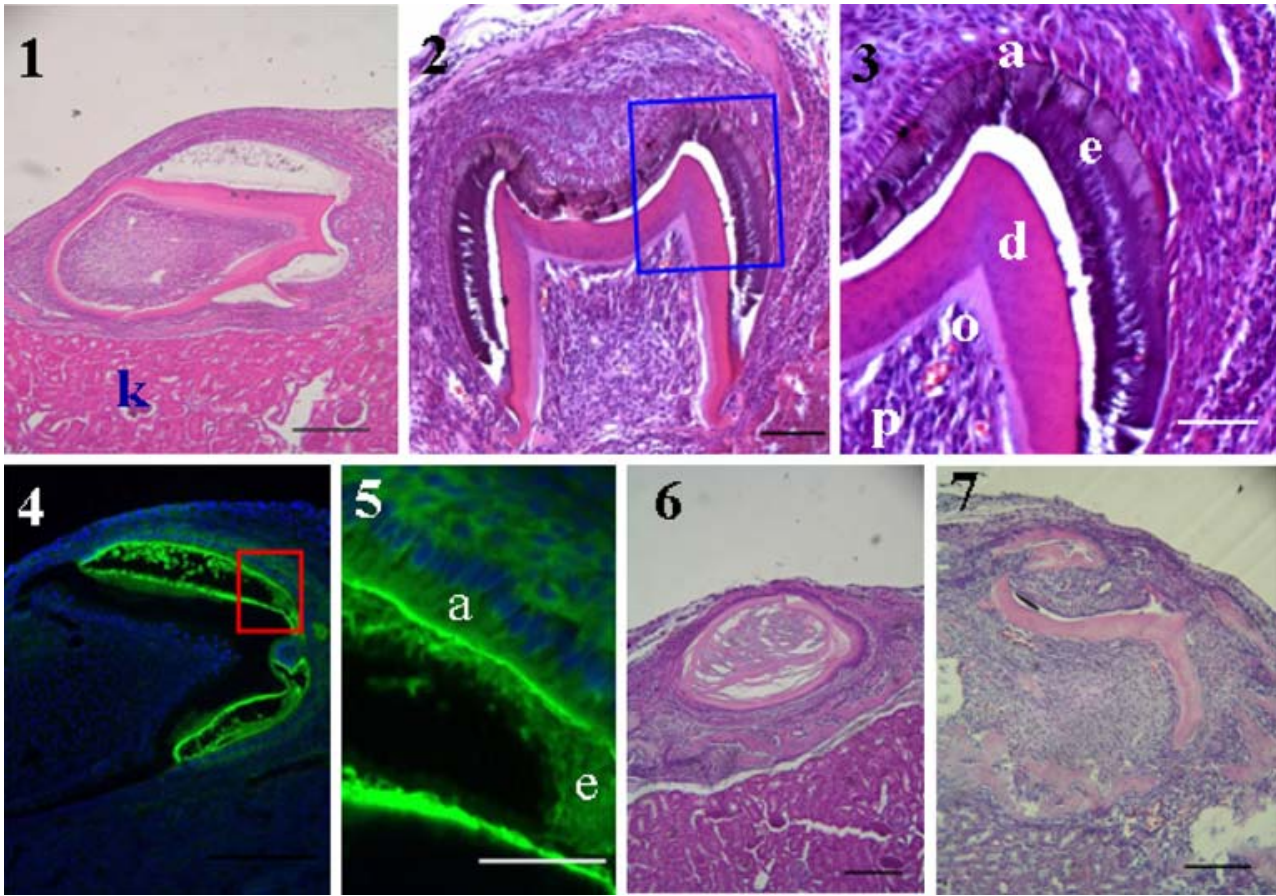
Table 3. Summary of regenerated structures from bioengineered dental germs

\begin{tabular}{llcr}
\hline Sample & Tooth & Others $^{\mathrm{c}}$ & Total \\
\hline Negative control $^{\mathrm{a}}$ & $0\left(0^{\mathrm{d}}\right)$ & 6 & 6 \\
Positive control $^{\mathrm{b}}$ & $6(86)$ & 1 & 7 \\
foec-2 $^{\text {foec-3 }}$ & $3(23)$ & 10 & 13 \\
foec-5 & $0(0)$ & 9 & 9 \\
foec-6 & $4(33)$ & 8 & 12 \\
foec-7 & $2(20)$ & 8 & 10 \\
foec-8 & $6(43)$ & 8 & 14 \\
\hline
\end{tabular}

${ }^{\text {a }}$ Dental germ without epithelial cells

${ }^{\mathrm{b}}$ Dental germ reconstructed with epithelia and mesenchyme prepared from fetuses

${ }^{\mathrm{c}}$ Bone or cornified tissues

${ }^{\mathrm{d}}$ Percent of tooth regeneration

lines established in the present study are derived from the oral epithelium

Induction of stratified oral epithelium. The question whether established cell lines are able to form stratified oral epithelium was addressed in two methods: culturing on feeder layer (O'Connor et al. 1981; Gallico et al. 1984) and on collagen matrix. All cell lines examined formed stratified epithelia in these methods. A differentiation marker of non-keratinized epithelium and a stem cell marker were detected as seen in fetal oral mucosa, although the expression patterns of differentiation markers in some reconstructed epithelia were slightly different from those observed in vivo. In heterotypic combination, mesenchyme induces weak or incomplete changes in cytokeratin expression of epithelial cells (Schweizer et al. 1984; Kautsky et al. 1995). In the present study, Balb/c 3 T3 cells were used, and they might have some heterotypic effects on oral epithelial cells in marker expression.

Regeneration of tooth. The question was addressed whether oral epithelial cell lines when incorporated in dental germs are able to differentiate into ameloblasts and regenerate tooth. Dental germs were reconstructed with epithelial cell lines and fetal mesenchyme and incubated under kidney capsule. Calcified teeth developed from germs prepared with epithelial cells of five among six lines. All teeth took molar shape because the mesenchymal tissues in germs were obtained from molar germs (Kollar and Baird 1969). Histological and immunohistochemical studies demonstrated that oral epithelial cell lines differentiated into ameloblasts, which was confirmed by labeling of implanted cells with GFP. Germs reconstructed with only mesenchymal cells developed bone, denying the possible contamination of reconstructed germs with dental epithelial cells.

The oral cavity is formed by involution of the ectoderm, and some of the covering epithelial cells are committed to differentiate into dental lamina, resulting in the formation of the dental arch invaginating into underlining presumptive dental mesenchyme during the early development of the mandible. As discussed above, all of the clonal cell lines expressed oral epithelial markers and had no expressions of dental epithelial markers. They were established from the oral epithelium of embryos at E18. At this stage in mouse, the dental epithelia or ameloblast progenitors are almost segregated from the oral epithelium, which is committed to cover the oral surface. Recently, it has been shown that an oral epithelial sheet prepared in culture had odontogenic potential when examined with our method (Nakao et al. 2007; Nakagawa et al. 2009).
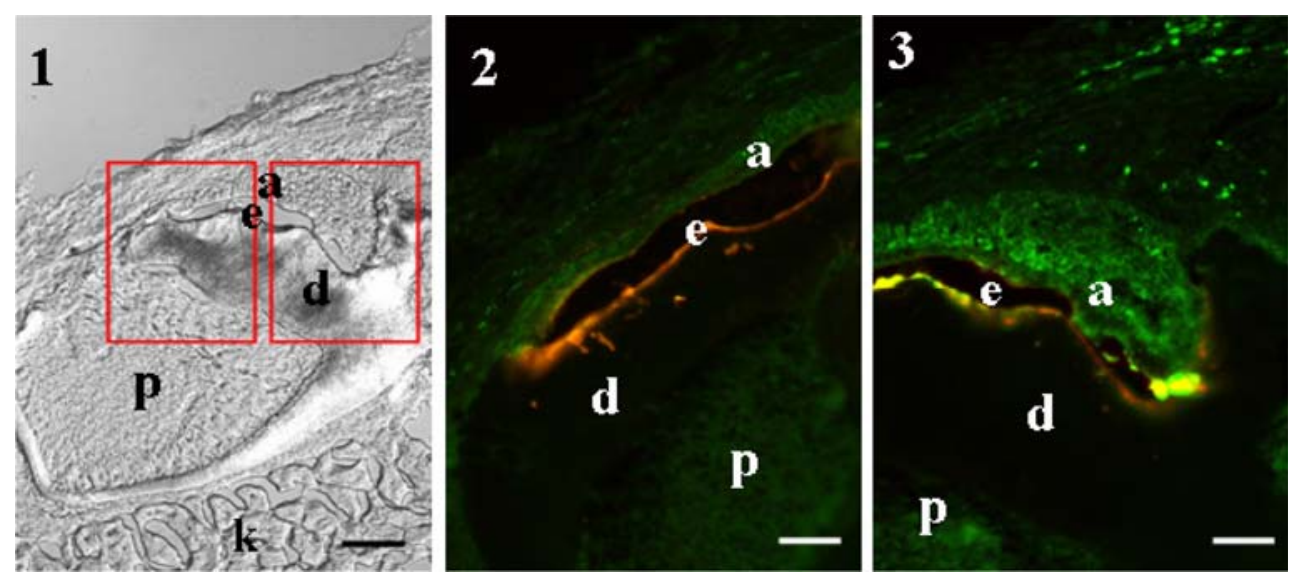

Figure 8. Ameloblasts were differentiated from implanted oral epithelial cells. Tooth germs were prepared with mesenchyme and GFP-expressing foec-5 cells. GFP-expressing foec-5 cells were found around the calcified tissues and differentiated into amelogenin positive ameloblasts. (1) was a whole image of a regenerated tooth. (2) and (3) were immunohistochemistry of amelogenin at high magnification of areas in rectangles in (1). $a$ ameloblast, $d$ dentin, $e$ enamel, $k$ kidney, $p$ dental pulp. green GFP, red amelogenin. Bar, $100 \mu \mathrm{m}$. 
Tissue recombinant method has been often used to study tissue interactions between epithelial and mesenchymal cells in organogenesis. Kollar and Baird (1970a, b) reconstructed dental germs with fragments of dental mesenchyme and ectopic epithelium. Germs prepared with lip-furrow epithelium (E15-16) and foot epithelium (E14-15) developed calcified teeth after incubation in eye chamber. The studies suggest that the dental mesenchyme has inductive activity on ectopic epithelia as well as homologous epithelium. The present study confirmed such inductive activity of the mesenchyme on clonal cell lines newly established from the oral epithelium.

Our method for tooth germ reconstruction gives rise to high efficiency of tooth regeneration (Nakao et al. 2007). All cell lines established from dental epithelia regenerated teeth (100\%; Komine et al. 2007). In the present study, five among six cell lines examined regenerated teeth $(83 \%)$. We have established cell lines from oral epithelia of a young adult mouse and examined them in the same regeneration assay. Two among eight lines regenerated teeth (25\%; unpublished observations). The variation in successful regeneration rate is caused by supplements in culture medium for cell lines prior to germ formation (unpublished observations). Taken together, the following hypotheses are proposed: (1) responsible cells to the inductive activity of mesenchyme will chronologically reduce in number in oral epithelia or (2) plasticity of fatedetermined cells (Horiuchi and Tomooka 2005) will be chronologically reduced. Media used for culture prior to germ formation can be improved by the addition of some factors or by conditioning with mesenchymal cells. Culture methods such as floating, three-dimensional, or adoption of matrices will be examined. These technical improvements will elicit new patterns of gene expression, resulting in an increase of the responsibility to the inductive activity or the plasticity.

The nature of the mesenchymal inductive activity is not known. The interaction between epithelia and mesenchyme is critical in morphogenesis at developmental stage. To investigate the inductive activity of dental mesenchyme, more than 100 clonal cell lines have been established from dental mesenchyme of a $p 53$-deficient fetal mouse (data not shown). Currently, they have been under investigation.

This is the first report on the establishment of oral epithelial cell lines which differentiate into stratified oral epithelium and into enamel secreting ameloblasts. These cell lines would be useful models in vitro to study oral development, mechanisms determining cell fate of oral epithelial cells, and regeneration of tooth.

Acknowledgments This work was supported by "Academic Frontier" project for Private Universities to Y.T. and T.T. (2003-2007) and by KAKENHI (20249078) (19570062). This research was partly conducted as the Research for Promoting Technological Seeds supported by JST Innovation Satellite Ibaraki. $p 53$-dificient mice were provided by Dr. S. Aizawa (REKEN Center for Developmental Biology).

Open Access This article is distributed under the terms of the Creative Commons Attribution Noncommercial License which permits any noncommercial use, distribution, and reproduction in any medium, provided the original author(s) and source are credited.

\section{References}

Byrne C.; Tainsky M.; Fuchs E. Programming gene expression in developing epidermis. Development 120: 2369-2383; 1994.

Chen L. S.; Couwenhoven R. I.; Hsu D.; Luo W.; Snead M. L. Maintenance of amelogenin gene expression by transformed epithelial cells of mouse enamel organ. Arch oral Biol 37: 771$778 ; 1992$.

DenBesten P. K.; Gao C.; Li W.; Mathews C. H. E.; Gruenert D. C. Development and characterization of an SV40 immortalized porcine ameloblast-like cell line. Eur J Oral Sci 107: 276-281; 1999.

DenBesten P. K.; Mathews C. H. E.; Gao C.; Li W. Primary culture and characterization of enamel organ epithelial cells. Connective Tissue Res 38: 3-8; 1998.

Feghali-Assaly M.; Sawaf M. H.; Serres G.; Forest N.; Ouhayoun J. P. Cytokeratin profile of the junctional epithelium in partially erupted teeth. J Periodontal Res 29: 185-195; 1994.

Fujii T.; Nakao F.; Shibata Y.; Shioi G.; Kodama E.; Fujisawa H.; Takagi S. Caenorhabditis elegans PlexinA, PLX-1, interacts with transmembrane semaphorins and regulates epidermal morphogenesis. Development 129: 2053-2063; 2002.

Gallico 3 rd G. G.; O’Connor N. E.; Compton C. C.; Kehinde O.; Green H. Permanent coverage of large burn wounds with autologous cultured human epithelium. $N$ Engl J Med 311: 448-451; 1984.

Gao A.; Mackenzie I. C. Patterns of phenotypic expression of human junctional, gingival and reduced enamel epithelia in vivo and in vitro. Epithelial Cell Biol 1: 156-167; 1992.

Hanazono M.; Hirabayashi K.; Tomisawa H.; Aizawa S.; Tomooka Y. Establishment of uterine cell lines from p53-deficient mice. In Vitro Cell Dev Biol Anim 33: 668-671; 1997.

Hanazono M.; Nakagawa E.; Aizawa S.; Tomooka Y. Establishment of prostatic cell line "Pro9ad" from a p53-deficient mouse. Prostate 36: 102-109; 1998.

Hanazono M.; Nozawa R.; Itakura R.; Aizawa S.; Tomooka Y. Establishment of an androgen-responsive prostatic cell line "PEA5" from a p53-deficient mouse. Prostate 41: 214-225; 2001.

Horiuchi M.; Tomooka Y. An attempt to generate neurons from astrocyte progenitor cell line FBD-104. Neuroscience Res 53: $104-115 ; 2005$.

Hu B.; Unda F.; Bopp-Kuchler S.; Jimenez L.; Wang X. J.; Haïkel Y.; Wang S. L.; Lesot H. Bone marrow cells can give rise to ameloblast-like cells. J Dent Res 85: 416-421; 2006.

Jackson B. W.; Grund C.; Winter S.; Franke W. W.; Illmensee K. Formation of cytoskeletal elements during mouse embryogenesis. II. Epithelial differentiation and intermediate-sized filaments in early postimplantation embryos. Differentiation 20: 203-216; 1981.

Jones P. H.; Harper S.; Watt F. M. Stem cell patterning and fate in human epidermis. Cell 80: 83-93; 1995.

Kagoshima M.; Ito T.; Kitamura H.; Goshima Y. Diverse gene expression and function of semaphorins in developing lung: positive and negative regulatory roles of semaphorins in lung branching morphogenesis. Genes to Cells 6: 559-571; 2001. 
Kautsky M. B.; Fleckman P.; Dale B. A. Retinoic acid regulates oral epithelial differentiation by two mechanisms. $J$ Invest Dermatol 104: 546-553; 1995.

Kawano S.; Morimoto T.; Toyono T.; Nakamura N.; Uchida T.; Ohishi M.; Toyoshima K.; Harada H. Establishment of dental epithelial cell line (HAT-7) and the cell differentiation dependent on Notch signaling pathway. Connect Tissue Res 43: 409-412; 2002.

Kollar E. J.; Baird G. R. The influence of the dental papilla on the development of tooth shape in embryonic mouse tooth germs. Embryol exp Morph 21: 131-148; 1969.

Kollar E. J.; Baird G. R. Tissue interactions in embryonic mouse tooth germs. I. Reorganization of the dental epithelium during toothgerm reconstruction. Embryol Exp Morph 24: 159-171; 1970a.

Kollar E. J.; Baird G. R. Tissue interactions in embryonic mouse tooth germs. II. The inductive role of the dental papilla. J Embryol Exp Morphol 24: 173-186; 1970 b.

Komine A.; Suenaga M.; Nakao K.; Tsuji T.; Tomooka Y. Tooth regeneration from newly established cell lines from a molar tooth germ epithelium. Biochem Biophys Res Commun 355: 758-763; 2007.

Koster M. I.; Kim S.; Mills A. A.; DeMayo F. J.; Roop D. R. p63 is the molecular switch for initiation of an epithelial stratification program. Genes Dev 18: 126-131; 2004.

Kukita A.; Harada H.; Kukita T.; Inai T.; Matsuhashi S.; Kurisu K. Primary and secondary culture of rat ameloblasts in serum-free medium. Calsif Tissue Int 51: 393-398; 1992.

Li A.; Pouliot N.; Redvers R.; Kaur P. Extensive tissue-regenerative capacity of neonatal human keratinocyte stem cells and their progeny. J Clin Invest 113: 390-400; 2004.

Lumsden A. G. S. Spatial organization of the epithelium and the role of neural crest cells in the initiation of the mammalian tooth germ. Development Suppl: 155-169; 1988.

Mackenzie I. C.; Rittman G.; Gao Z.; Leigh I.; Lane E. B. Patterns of cytokeratin expression in human gingival epithelia. $J$ Periodontal Res 26: 468-478; 1991.

Mass R.; Bei M. The genetic control of early tooth development. Crit Rev Oral Biol Med 8: 4-39; 1997.

Matsumura T.; Tabata M. J.; Wakisaka S.; Sakuda M.; Kurisu K. Ameloblast-lineage cells of rat tooth germs proliferate and scatter in response to hepatocyte growth factor in culture. Int J Dev Biol 42: 1137-1142; 1998.

Miletich I.; Sharpe P. T. Normal and abnormal dental development. Hum Mol Genet 12: R69-R73; 2003.

Mina M.; Kollar E. J. The induction of odontogenesis in non-dental mesenchyme combined with early murine mandibular arch epithelium. Archs oral Biol 32: 123-127; 1987.

Minakawa M.; Sugimoto T.; Aizawa S.; Tomooka Y. Cerebellar cell lines established from a p53-deficient adult mouse. Brain Res 813: 172-176; 1998.

Miyasaki K. T.; Bodeau A. L.; Ganz T.; Selsted M. E.; Lehrer R. I. In vitro sensitivity of oral, Gram-negative, facultative bacteria to the bactericidal activity of human neutrophil defensins. Infect Immun 58: 3934-3940; 1990.

Moll R.; Franke W. W.; Schiller D. L.; Geiger B.; Krepler R. The catalog of human cytokeratins: patterns of expression in normal epithelia, tumors and cultured cells. Cell 31: 11-24; 1982.

Nakagawa E.; Itoh T.; Yoshie H.; Satokata I. Odontogenic potential of post-natal oral mucosal epithelium. J Dent Res 88: 219-223; 2009.
Nakao K.; Morita R.; Saj Y.; Ishida K.; Tomita Y.; Ogawa M.; Saitoh M.; Tomooka Y.; Tsuji T. The development of a bioengineered organ germ method. Nature Methods 4: 227-230; 2007.

Nakata A.; Kameda T.; Nagai H.; Ikegami K.; Duan Y.; Terada K.; Sugiyama T. Establishment and characterization of a spontaneously immortalized mouse ameloblast-lineage cell line. Biochem Biophys Res Commun 308: 834-839; 2003.

O'Connor N. E.; Mllliken J. B.; Banks-Schlegel S.; Kehinde O.; Green H. Grafting of burns with cultured epithelium prepared from autologous epidermal cells. Lancet 1: 75-78; 1981.

Ohazama A.; Modino S. A.; Miletich I.; Scarpe P. T. Stem-cell-based tissue engineering of murine teeth. $J$ Dent Res 83: 518-522; 2004.

Perälä N. M.; Immonen T.; Sariola H. The expression of plexins during mouse embryogenesis. Gene Expr Patterns 5: 355-362; 2005.

Schoop V. M.; Mirancea N.; Fusenig N. E. Epidermal organization and differentiation of $\mathrm{HaCaT}$ keratinocytes in organotypic coculture with human dermal fibroblasts. $J$ Invest Dermatol 112: 343-353; 1999.

Schweizer J.; Winter H.; Hill M. W.; Mackenzie I. C. The keratin polypeptide patterns in heterotypically recombined epithelia of skin and mucosa of adult mouse. Differentiation 26: 144-153; 1984.

Tanahashi K.; Shibahara S.; Ogawa M.; Hanazono M.; Aizawa S.; Tomooka Y. Establishment and characterization of clonal cell lines from the vagina of p53-deficient young mice. In Vitro Cell Dev Biol Anim 38: 547-556; 2002.

Tani H.; Morris R. J.; Kaur P. Enrichment for murine keratinocyte stem cells based on cell surface phenotype. Proc Natl Acad Sci USA 97: 10960-10965; 2000.

Thesleff I. Developmental biology and building a tooth. Quintessence Int 34: 613-620; 2003.

Tomooka Y.; Aizawa S. Cell lines established from fetal brains of p53deficient mice. Cell Struct Funct 23: 101-107; 1998.

Tomooka Y.; Kitani H.; Jing N.; Matsushima M.; Sakakura T. Reconstruction of neural tube-like structures in vitro from primary neural precursor cells. Proc Natl Acad Sci USA 90: 9683-9687; 1993.

Toyofuku T.; Zhang H.; Kumanogoh A.; Takegahara N.; Suto F.; Kamei J.; Aoki K.; Yabuki M.; Hori M.; Fujisawa H.; Kikutani H. Dual roles of Sema6D in cardiac morphogenesis through region-specific association of its receptor, Plexin-A1, with offtrack and vascular endothelial growth factor receptor type 2 . Genes Dev 18: 435-447; 2004.

Tsukada T.; Tomooka Y.; Takai S.; Ueda Y.; Nishikawa S.; Yagi T.; Tokunaga T.; Takeda N.; Suda Y.; Abe S.; Matsuo I.; Ikawa Y.; Aizawa S. Enhanced proliferative potential in culture of cells from p53-deficient mice. Oncogene 8: 3313-3322; 1993.

Umezu T.; Hanazono M.; Aizawa S.; Tomooka Y. Characterization of newly established clonal oviductal cell lines and differential hormonal regulation of gene expression. In Vitro Cell Dev Biol Anim 39: 146-156; 2003.

Yang A.; Kaghad M.; Wang Y.; Gillett E.; Fleming M. D.; Dötsch V.; Andrews N. C.; Caput D.; McKeon F. p63, a p53 homolog at 3q2729 , encodes multiple products with transactivating, death-inducing, and dominant-negative activities. Mol Cell 2: 305-316; 1998. 